\title{
ANALISA POTENSI EMBUNG ITERA SEBAGAI PEMBANGKIT LISTRIK TENAGA PICO HYDRO (PLTPH)
}

\author{
Dean Corio*, Kiki Kananda, dan Khansa Salsabila S \\ Program Studi Teknik Elektro, Institut Teknologi Sumatera \\ ${ }^{*}$ Corresponding author, e-mail: dean.corio@el.itera.ac.id
}

\begin{abstract}
Abstrak - Institut Teknologi Sumatera (ITERA) memiliki 5 embung dengan konstruksi bibir embung lebih tinggi dari batas muka air normalnya serta memiliki elevasi curam dengan luasan Daerah Tangkapan Air (DTA) masing masing-nya berbeda. Melalui software Google Earth Pro diketahui luas DTA embung A, B, C, D, dan E secara berturut-turut yaitu 1,728 ha; 1,146 ha; 1,052 ha; 0,844 ha; dan 9,562 ha. Penelitian ini bertujuan untuk mengetahui potensi energi yang mungkin dibangkitkan dari 5 embung tersebut dengan tetap mempertimbangkan keutuhan ekosistemnya. Pembangkit berupa pembangkit listrik tenaga pico hydro yang dapat digunakan sebagai media praktikum pembangkit tenaga listrik oleh mahasiswa Itera, khususnya mahasiswa program studi teknik elektro. Pipa pesat pembangkit listrik didesain terpasang 1 meter dibawah muka air normal dan waktu pengoperasian berdasarkan debit hujan yang tertampung oleh embung dalam satu bulan. Metoda yang dilakukan adalah observasi lapangan, pengumpulan data curah hujan, perhitungan menggunakan metode rasional praktis dan persamaan daya hidraulik tenaga air. Hasil pengolahan data lima embung yang dimiliki Itera didapatkan potensi terbesar yang bisa dimanfaatkan sebagai sumber pembangkit listrik adalah embung E. Hasil analisa menunjukkan debit tampungan $0,216 \mathrm{~m}^{3} / \mathrm{s}$ dan head efektif 5,46 m dapat menghasilkan daya listrik terbangkitkan sebesar 7,071 kW dengan waktu operasional pada bulan April.
\end{abstract}

\section{Kata Kunci : Debit, Intensitas Hujan, Pico Hydro.}

\begin{abstract}
Institut Teknologi Sumatera (ITERA) has 5 reservoirs with lip embankment construction higher than the normal water level and have steep elevations with different catchment areas (DTA). By using the Google Earth Pro software, it is known that DTA reservoirs A, B, C, D, and E are respectively $1.728 \mathrm{ha} ; 1,146 \mathrm{ha} ; 1,052 \mathrm{ha} ; 0.844 \mathrm{ha}$; and $9.562 \mathrm{ha}$. This study aims to determine the potential energy that might be generated from the 5 reservoirs while still considering the integrity of the ecosystem. The power plant is in the form of a Pico hydro power plant that can be used as a power plant practicum media by Itera students, especially electrical engineering study program students. The power plant's rapid pipe is designed to be installed 1 meter below the normal water level and the operating time is based on the rain discharge that is accommodated by the reservoir in one month. The method used is field observation, rainfall data collection, calculations using practical rational methods and hydropower hydraulics. The results of data processing of five reservoirs owned by ITERA show that the greatest potential that can be used as a source of electricity generation is reservoirs E. The analysis shows that the discharge capacity of $0.216 \mathrm{~m} 3 / \mathrm{s}$ and an effective head of $5.46 \mathrm{~m}$ can produce an electric power generated of 7,071 $\mathrm{kW}$ with operational time at April.
\end{abstract}

Keywords : Discharge, Rain Intensity, Pico Hydro.

\section{Pendahuluan}

Energi terbarukan merupakan alternatif untuk mengurangi pemakaian bahan bakar fosil dalam pembangkitan energi listrik. Sumber energi terbarukan tersebut tersebar sesuai potensi daerah di Indonesia, seperti potensi air, angin, gelombang laut, panas bumi, dan lainnya. Sumatera yang memiliki curah hujan tinggi setiap tahunnya serta memiliki gugusan Bukit Barisan mempunyai potensi besar untuk pembangkit listrik tenaga air. Beberapa kendala dinas Energi dan Sumber Daya Mineral (ESDM) di Sumatera adalah kurangnya minat investor dibidang energi, kurang akuratnya pemetaan potensi dan kurangnya tenaga ahli yang mumpuni dibidang pembangkitan energi air. 
Itera yang letaknya berada di perbatasan dua kabupaten/kota memiliki potensi pembangkit energi berupa embung dengan luas dan kedalaman yang berbeda-beda. Embung ini dapat menjadi sumber pembangkit picohydro, karena konstruksi saluran pembuangan embung membantu kebutuhan head (beda ketinggian permukaan) yang mana akan mempengaruhi besar tenaga air[1]. Pembangkit listrik tenaga picohydro adalah pembangkit listrik skala kecil yang menggunakan tenaga air sebagai penggeraknya dengan kapasitas dibawah $5 \mathrm{kVA}[2]$.

Analisa potensi sumber air untuk pembangkit listrik tenaga air telah dilakukan oleh beberapa peneliti sebelumnya. I Wayan Ratnata, Wasimudin Surya S, dan Maman Somantri (2013), melakukan penelitian potensi sungai Cibeureum yang terletak di belakang Universitas Pendidikan Indonesia untuk menjadi pembangkit listrik tenaga mikrohidro. Metode yang digunakan yaitu pengkajian literatur PLTMH, pengukuran debit air menggunakan alat ukur jenis digital water current meter, pengukuran head menggunakan alat ukur jenis theodolit total station topcon GT105, dan perhitungan potensi hidraulik dan kapasitas daya terbangkit[3].

Albastomiroji (2018) melakukan penelitian untuk menghitung potensi dari daya terbangkit Bendung Trani Kali Samin/Gembong di Kabupaten Sukoharjo untuk PLTMH. Ia menggunakan koordinat google maps untuk mencari head dan metode apung untuk mengetahui debit alirannya, sedangkan potensi daya yang dibangkitkan dihitung dengan persamaan daya hidraulik air dikalikan efisiensi[4].

Berdasarkan latar belakang diatas dan penelitian-penelitian sebelumnya, maka penelitian ini bertujuan untuk mengetahui potensi yang dimiliki 5 embung Itera, yaitu embung A, embung $\mathrm{B}$, embung $\mathrm{C}$, embung $\mathrm{D}$, dan embung $\mathrm{E}$ dengan mempertimbangkan keutuhan ekosistemnya. Harapannya analisa ini dapat menjadi acuan untuk mengembangkan pembangkit listrik tenaga picohydro di itera sehingga dapat digunakan sebagai media praktikum pembangkit tenaga listrik oleh mahasiswa Itera, khususnya mahasiswa program studi teknik elektro.

\section{Metodologi}

Penelitian ini dilakukan di Institut Teknologi Sumatera yang beralamat di Jl. Terusan Ryacudu,
Desa Way Hui, Kecamatan Jati Agung, Lampung Selatan. Metode yang dilakukan pada penelitian ini yaitu pengumpulan data klimatologi, observasi lapangan, desain tinggi dan letak powerhouse, penentuan parameter efisiensi, pengolahan data, dan penentuan potensi embung. Gambar 1 menunjukkan diagram alir analisa potensi embung Itera untuk desain pembangkit picohydro sebagai media pembelajaran mahasiswa.

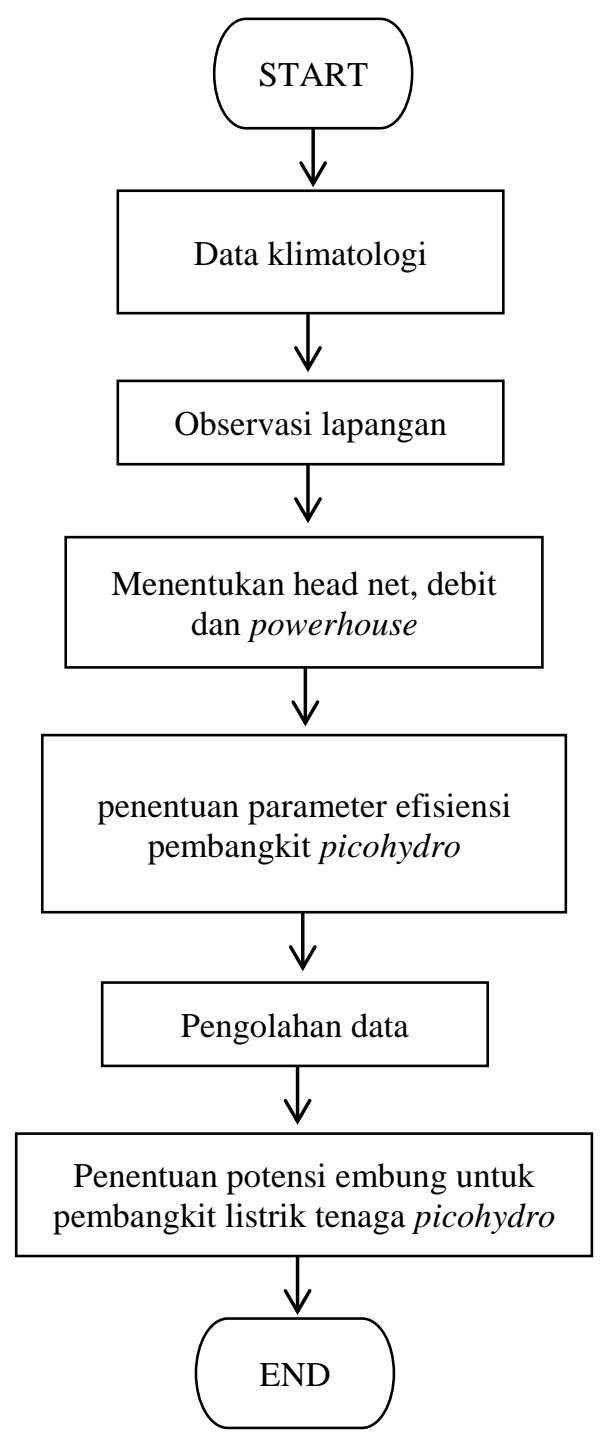

Gambar 1. Metode Penelitian.

\subsection{Data klimatologi}

Data klimatologi diperoleh dari pencatatan MKG (Meteorologi, Klimatologi, dan geofisika) Itera. Pencatatan data curah hujan berada dalam periode 10 menit untuk semua hari di tiap bulan dalam satuan $\mathrm{mm}$. 


\subsection{Observasi lapangan}

Observasi lapangan dilakukan untuk menentukan head (beda ketinggian permukaan) pada lima lokasi embung di Itera, yaitu embung $\mathrm{A}$, embung $\mathrm{B}$, embung $\mathrm{C}$, dan embung $\mathrm{D}$, dan menentukan batas DTA (Daerah Tangkapan Air) pada masing-masing embung, sedangkan penentuan luas DTA dilakukan melalui software Google Earth Pro. Selain itu pada observasi lapangan dilakukan penilaian karakteristik lahan embung untuk menentukan koefisien limpasan.

\subsection{Deain letak dan tinggi powerhouse}

Powerhouse digunakan sebagai bangunan untuk melindungi peralatan-peralatan pembangkit listrik seperti turbin, generator, dan lainnya dari gangguan-gangguan. Bangunan ini didesain memiliki tinggi $1,5 \mathrm{~m}$ dan terletak di ujung saluran pembuangan embung.

\subsection{Parameter efisiensi}

Efisiensi yang digunakan untuk menentukan daya terbangkitkan terdiri dari konstruksi sipil, penstock, turbin, generator, sistem kontrol, jaringan, dan trafo.

\subsection{Pengolahan data}

Pengolahan data dilakukan untuk memperoleh daya terbangkitkan pada tiap embung berdasarkan parameter-parameter yang telah diketahui, yaitu intensitas hujan, luas DTA embung, parameter efisiensi, dan head bersih yang diperoleh dari data head embung hasil observasi dikurangi rencana tinggi powehouse.

\subsection{Penentuan Potensi}

Penentuan potensi dilakukan berdasarkan hasil pengolahan data, yaitu daya terbesar yang dapat dihasilkan oleh embung sebagai sumber pembangkit listrik picohydro.

\section{Desain Pembangkit Listrik dan Pengolahan Data Lapangan}

Embung Itera adalah danau buatan yang menampung air hujan. Konstruksi embung ini didesain memiliki lereng landai disekelilingnya dan memiliki saluran pembuangan yang mengatur muka air normal embung. Tingkat pertambahan air embung bergantung pada tingkat intensitas hujan, penyinaran matahari, penggunaan lahan, evapotranspirasi, perembesan, dll [2][3]. Melalui data intensitas hujan, luas embung, dan kondisi penggunaan lahan embung dapat diperkirakan besar debit yang akan masuk ke embung. Data ini akan menjadi pertimbangan penggunaan embung sebagai sumber pembangkit picohydro tanpa merusak ekosistemnya.

Penyaluran air ke turbin menggunakan pipa yang dipasang 1 meter dibawah muka air normal, diameter pipa ditentukan berdasarkan banyaknya debit air yang akan dialirkan selama beroperasi, dan panjang pipa berbeda-beda untuk tiap embung yaitu berdasarkan hasil observasi lapangan untuk menentukan head. Tabel 1 menunjukkan head pada 5 lokasi embung Itera.

Tabel 1. Head embung Itera

\begin{tabular}{|c|c|c|}
\hline No & Nama Embung & Head $(\mathrm{m})$ \\
\hline 1 & A & 2,92 \\
\hline 2 & B & 3,02 \\
\hline 3 & C & 5,88 \\
\hline 4 & D & 3,59 \\
\hline 5 & E & 6,96 \\
\hline
\end{tabular}

Besarnya debit air yang digunakan harus selalu terkontrol dan dibatasi agar tidak menggangu ekosistem embung. Merujuk pada tingginya curah hujan Sumatera setap tahun dapat digunakan untuk mempertahankan batas normal air dalam masa pengoperasian. Banyaknya air hujan yang dapat ditampung oleh catchment area (daerah tangkapan air) harus dapat mengimbangi penggunaan untuk pembangkit listrik. Pembangkit energi listrik dengan sumber daya air bisa dioperasikan dan dihentikan pemakaiannya setiap saat dan mudah dioperasikan. Dengan peralatan yang mutakhir dapat digunakan selama lebih dari 50 tahun. Jadi dapat dikatakan ketangguhan sistemnya dapat dihandalkan.

Pengolahan data lapangan menggunakan persamaan berikut.

\section{a. Metode Rasional Praktis}

Metode rasional adalah metode paling sederhana untuk menentukan debit dari limpasan drainase. Dari persamaan ini dapat diketahui hubungan antara debit limpasan dengan besar intensitas hujan untuk luas DAS hingga 5000 hektar[1][4]. Debit limpasan menunjukkan banyaknya debit yang dapat bertambah ketika terjadi hujan. Debit limpasan dapat ditentukan dengan persamaan:

$Q=0,00278 \times C \times I \times A$

\section{Keterangan:}


$Q=$ debit limpasan $\left(\mathrm{m}^{3} / \mathrm{s}\right)$

$C=$ koefisien limpasan

$I=$ intensitas curah hujan $(\mathrm{mm} / \mathrm{jam})$

$A=$ luas daerah tampungan $(H A)$

\section{b. Efisiensi}

Dalam suatu sistem terdapat rugi-rugi yang mempengaruhi hasil kerja sistem tersebut, yang nilainya bergantung pada keadaan sistem di lapangan. Turbin memiliki kinerja yang berbedabeda bergantung pada tinggi terjun maksimum, tinggi terjun minimum, tinggi terjun normal, dan tinggi terjun rancangan[8]. Efisiensi maksimum turbin dapat tercapai apabila berada pada kecepatan terbaiknya yang dipengaruhi oleh tinggi terjun air. Efisiensi yang diperhitungkan pada analisa ini ditunjukkan oleh Tabel 2. dan efisiensi total $\left(\mathrm{n}_{o}\right) 0,43-0,72$, yaitu:

$$
\begin{aligned}
\eta_{o}=\eta_{\text {konstruksi }} & \times \eta_{\text {penstock }} \times \eta_{\text {turbin }} \\
& \times \eta_{\text {generator }} \times \eta_{\text {sistem kontrol }} \\
& \times \eta_{\text {jaringan }} \times \eta_{\text {trafo }}
\end{aligned}
$$

Tabel 2. Rentang efisiensi diperhitungkan

\begin{tabular}{|c|l|c|}
\hline No & \multicolumn{1}{|c|}{ Jenis Efisiensi } & Rentang Nilai \\
\hline 1 & Konstruksi Sipil & 1 \\
\hline 2 & Penstock & $0,9-0,95$ \\
\hline 3 & Turbin & $0,7-0,85$ \\
\hline 4 & Generator & $0,8-0,95$ \\
\hline 5 & Sistem Kontrol & 0,97 \\
\hline 6 & Jaringan & $0,9-0,98$ \\
\hline 7 & Trafo & 0,98 \\
\hline
\end{tabular}

c. Daya hidraulik tenaga air

Besarnya tenaga air yang tersedia dari suatu sumber air bergantung pada besarnya head efektif dan debit air. Head efektif adalah beda ketinggian antara muka air dengan muka air keluar turbin air. Dalam penelitian ini head efektif mempertimbangkan tinggi powerhouse. Daya hidraulik yang akan dikeluarkan dari air yang jatuh dinyatakan dengan persamaan berikut[2]:

$P_{\text {air }}=\rho g Q H_{e f f}$

Keterangan :

$P_{\text {air }}=$ daya hidraulik $[k W]$

$\rho=$ densitas air $\left[\mathrm{kg} / \mathrm{m}^{3}\right]$

$g=$ percepatan gravitasi $\left[9,81 \mathrm{~m} / \mathrm{s}^{3}\right]$

$Q=$ debit $\left[\mathrm{m}^{3} / \mathrm{s}\right]$
$H_{\text {eff }}=$ tinggi jatuh air $[\mathrm{m}]$

Dengan memperhatikan efisiensi keseluruhan, daya listrik yang dihasilkan adalah daya hidraulik air dikalikan dengan efisiensi total. Secara matematis dinyatakan sebagai berikut:

$P=\eta_{o} \times P_{\text {air }}$

atau

$P=\eta_{o} \times \rho \times g \times Q \times H_{e f f}$

Keterangan :

$P=$ daya listrik $[k W]$

$\eta_{o}=$ efisiensi

\section{Hasil dan Pembahasan}

\section{a. Analisis Debit Tampungan Embung}

Intensitas hujan adalah jumlah curah hujan dalam suatu satuan waktu tertentu, yang biasanya dinyatakan dalam $\mathrm{mm} / \mathrm{jam}, \mathrm{mm} / \mathrm{hari}, \mathrm{mm} / \mathrm{tahun}$, dan sebagainya[9]. Hasil pengolahan data MKG Itera yaitu intensitas hujan selama satu jam yang terjadi di satu hari. Kemudian data dikelompokkan berdasarkan bulan untuk mengetahui intensitas hujan terbesar dan terkecil yang terjadi pada bulan tersebut. Hasil pengolahan data ditunjukkan pada Gambar 2 berikut.

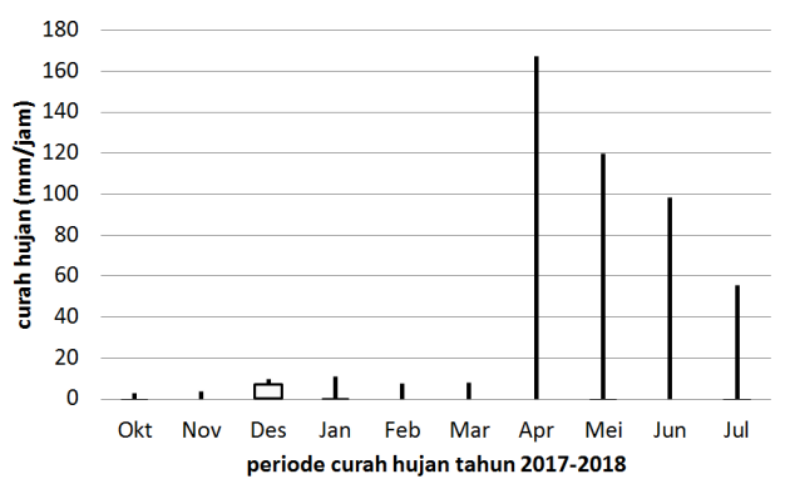

Gambar 2. Stock intensitas hujan periode Oktober 2017 - Juli 2018.

Gambar 2 adalah diagram stock yang menunjukkan intensitas hujan terbesar dan terkecil pada 10 bulan pengamatan beserta perubahan intensitasnya, bertambah atau berkurang. Bulan Oktober - November adalah waktu dimana intensitas hujan sangat rendah, dimana intensitas hujan tertingginya $2,658 \mathrm{~mm} / \mathrm{jam}$ dan 3,733 
$\mathrm{mm} / \mathrm{Jam}$. Bulan Desember terjadi hujan dengan intensitas tertinggi sebesar $9,717 \mathrm{~mm} / \mathrm{jam}$ dan mengalami pertambahan intensitas hujan selama tiga hari di akhir bulan. Kemudian pada bulan Januari, Februari, dan Maret terjadi hujan dengan intensitas tertingginya berturut-turut adalah 11,1 $\mathrm{mm} / \mathrm{jam}, 7,533 \mathrm{~mm} / \mathrm{jam}$, dan 7,933 mm/jam. Dari 10 bulan pengamatan tersebut Intensitas hujan tertinggi terjadi pada bulan April yaitu 167,158 $\mathrm{mm} / \mathrm{jam}$, diikuti bulan Mei, Juni, dan Juli yaitu berturut-turut sebasar $119,892 \mathrm{~mm} / \mathrm{jam}, \quad 98,4$ $\mathrm{mm} / \mathrm{jam}$, dan 55,675 mm/jam.

Luas DTA embung dapat diketahui dengan fitur ruler polygon. Hal ini ditentukan berdasarkan karakteristik aliran permukaan tanah yang akan mengalir dari daerah tinggi ke daerah rendah memasuki DTA. Hasil pengukuran melalui software Google Earth Pro ditunjukkan oleh Tabel 3.

Tabel 3. Luas DTA Embung Itera

\begin{tabular}{|c|c|c|c|c|c|}
\hline $\begin{array}{c}\text { Nama } \\
\text { Embung }\end{array}$ & A & B & C & D & E \\
\hline Luas (HA) & 1.728 & 1.146 & 1.052 & 0.844 & 9.562 \\
\hline
\end{tabular}

Tabel 3 menunjukkan bahwa luas DTA embung di itera bervariasi. Luas terkecil adalah embung D yaitu 0,844 hektar dan luas terbesar adalah embung E yaitu 9,562 hektar. Urutan luas DTA dari yang paling kecil ke paling besar secara berturut-turut adalah DTA embung D, DTA embung C, DTA embung B, DTA embung A, dan DTA embung E.

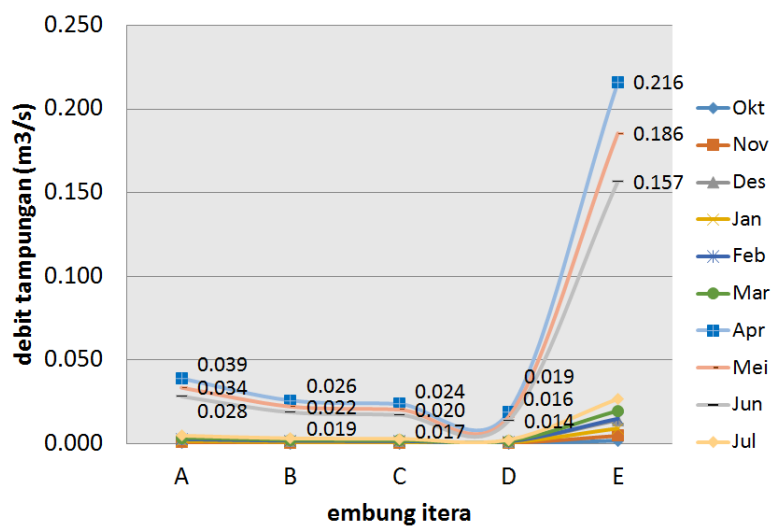

Gambar 3. Besar debit yang bertambah pada tiap embung.

Debit yang akan mengisi embung dihitung melalui metode rasional praktis seperti pada persamaan (1). Parameter yang diperlukan yaitu koefisien limpasan, data luas DTA embung pada tabel 3, dan intensitas hujan. Berdasarkan bentuk muka DTA embung itera dan mengacu pada data SNI 2415:2016, koefisien limpasan yang digunakan dalam perhitungan yaitu $40 \%$. Hasil perhitungan debit tampungan untuk tiap embung pada periode Oktober 2017 - Juli 2018 ditunjukkan oleh Gambar 3.

Debit terbesar pada embung A sebesar 0,039 $\mathrm{m}^{3} / \mathrm{s}$, debit terbesar pada embung B sebesar $0,026 \mathrm{~m}^{3} / \mathrm{s}$, debit terbesar pada embung C sebesar $0,024 \mathrm{~m}^{3} / \mathrm{s}$, debit terbesar pada embung D sebesar $0,019 \mathrm{~m}^{3} / \mathrm{s}$, dan debit terbesar embung E sebesar $0,216 \mathrm{~m}^{3} / \mathrm{s}$. Dari gambar 3 dapat diketahui bahwa debit tampungan terbesar terjadi pada bulan April, Mei, dan Juni yang ditunjukkan oleh tiga line teratas pada diagram.

\section{b. Analisis Potensi Embung untuk Pembangkit Picohydro}

Besarnya daya terbangkitkan bergantung pada empat variabel, yaitu head efektif, gaya gravitasi, efisiensi total, dan debit air. Besar gaya gravitasi sesuai ketetapan adalah $9,81 \mathrm{~m}^{3} / \mathrm{s}$. Efisiensi untuk embung A 0,6. Efisiensi untuk embung B 0,601. Efisiensi untuk embung $C$ 0,612. Efisiensi untuk embung D 0,606. Efisiensi untuk embung $\mathrm{E}$ 0,613. Head atau beda ketinggian permukaan diukur menggunakan alat rangefinder, yaitu dengan menembakkan titik pandang alat ke permukaan yang diukur. Nilai yang ditampilkan alat kemuadian dikurangi tinggi pengamat untuk diperoleh head embung. Berdasarkan hasil observasi lapangan, head embung Itera bervariasi dari 2,92 m hingga 5,96 m. Head terendah adalah embung A dan head tertinggi adalah embung E.

Setelah nilai head bersih dan debit diperoleh, besarnya daya listrik terbangkitkan pada tiap embung sesuai persamaan (3) ditunjukkan oleh Gambar 4. Diagram ini menunjukkan 5 potensi embung itera berdasarkan plot hubungan head bersih, debit tampungan, dan daya terbangkitkan pada tiap embung dalam skala logaritmik.

Embung A yang ditunjukkan oleh garis biru point wajik dengan besar head efektif $1,42 \mathrm{~m}$ dan debit aliran $0,038 \mathrm{~m}^{3} / \mathrm{s}$, menghasilkan daya listrik sebesar 0,326 kW. Embung B yang ditunjukkan oleh garis coklat point persegi dengan besar head efektif $1,52 \mathrm{~m}$ dan debit aliran $0,026 \mathrm{~m}^{3} / \mathrm{s}$, menghasilkan daya listrik sebesar $0,232 \mathrm{~kW}$. Embung $\mathrm{C}$ yang ditunjukkan oleh garis abu-abu point segitiga dengan besar head efektif $4,38 \mathrm{~m}$ dan debit aliran $0,024 \mathrm{~m}^{3} / \mathrm{s}$, menghasilkan daya 
listrik sebesar 0,625 kW. Embung D yang ditunjukkan oleh garis kuing point silang dengan besar head efektif 2,09 $\mathrm{m}$ dan debit aliran 0,019 $\mathrm{m}^{3} / \mathrm{s}$, menghasilkan daya listrik sebesar 0,237 $\mathrm{kW}$. Embung $\mathrm{E}$ yang ditunjukkan oleh garis biru point silang dengan besar head efektif $5,46 \mathrm{~m}$ dan debit aliran $0,216 \mathrm{~m}^{3} / \mathrm{s}$, menghasilkan daya listrik sebesar 7,091 kW.

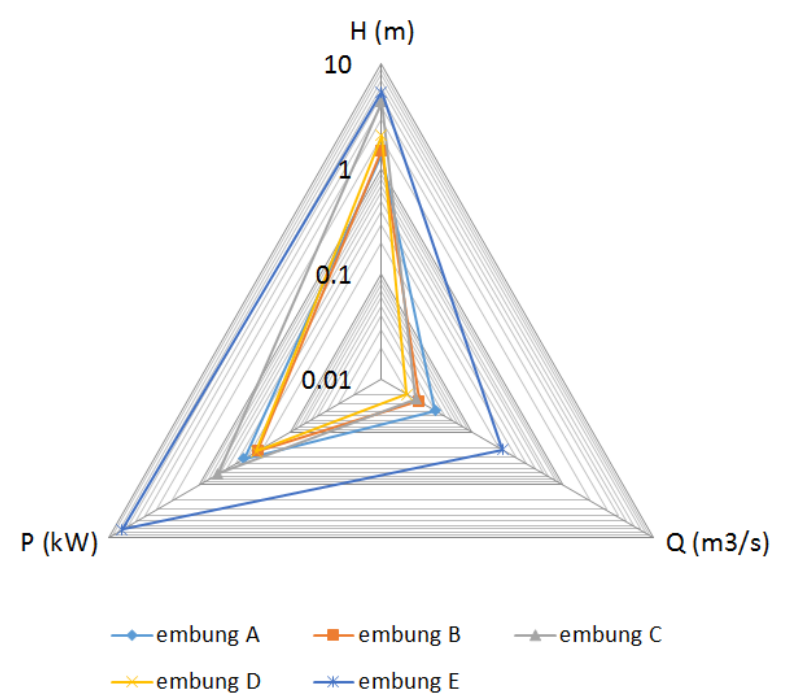

Gambar 4. Diagram potensi embung.

\section{Kesimpulan}

Dari hasil pengukuran, perhitungan, dan analisa yang telah dilakukan, dapat disimpulkan sebagai berikut:
a. Intensitas hujan tertinggi terjadi di bulan April yaitu sebesar $20,312 \mathrm{~mm} / \mathrm{jam}$.
b. Waktu pengoperasian pembangkit listrik tenaga picohydro terbaik yaitu pada bulan April.
c. Debit tampungan embung A, B, C, D, dan E secara berurutan yaitu $0,039 \mathrm{~m}^{3} / \mathrm{s}, 0,026 \mathrm{~m}^{3} /$ $\mathrm{s}, 0,024 \mathrm{~m}^{3} / \mathrm{s}, 0,019 \mathrm{~m}^{3} / \mathrm{s}$, dan $0,216 \mathrm{~m}^{3} / \mathrm{s}$
d. Potensi embung itera terbesar sebaai sumber pembangkit listrik adalah embung E yang mampu menghasilkan daya $7.091 \mathrm{~kW}$.

\section{Ucapan Terima Kasih (Acknowledgement)}

Penulis mengucapkan terima kasih atas pendanaan oleh Institut Teknologi Sumatera melalui program Hibah Mandiri ITERA Smart dengan SK No. 808/PPK/SK/XI/2018.

\section{Daftar Pustaka}

[1] K. C. Anup, G. Poudel, S. Poudel, and M. Khadka, "Hydro home system - An inventory on rural electrification," 2010 2nd Int. Conf. Comput. Autom. Eng. ICCAE 2010, vol. 5, no. January 2014, pp. 338-341, 2010.

[2] A. Multi, "Rancang Bangun Pembangkit Listrik Pikohidro 1000 VA dengan Memanfaatkan Pembuangan Air Limbah Pada Gedung Pakarti Centre," no. May, 2018.

[3] I. W. Ratnata, W. S. S, and M. Somantri, "Analisis Potensi Pembangkit Energi Listrik Tenaga Air di Saluran Air Sekitar Universitas Pendidikan Indonesia," FPTK Expo 2013, pp. 254-261, 2013.

[4] Albastomiroji, "Studi Kelayakan Potensi Pembangkit Listrik Tenaga Mikrohidro (PLTMH) Bendung Trani Kali Samin/Gembong di Kabupaten Sukoharjo," Universitas Muhammadiyah Surakarta, 2018.

[5] M. Yelza, J. Nugroho, and S. Natasaputra, "Pengaruh perubahan tataguna lahan terhadap debit limpasan drainase di kota bukittinggi," no. 10, pp. 1-18.

[6] D. H. Siregar, "Analisa Kapasitas Tampungan Penyimpanan Air di Catchment Area Danau Toba," Sumatera Utara, 2010.

[7] Badan Standardisasi Nasional, Tata Cara Perhitungan Debit Banjir Rencana. Jakarta: SNI 2415:2016, 2016.

[8] R. G. S. Putra, N. R. Ismail, and N. Fuhaid, "Pengaruh Pemberat Pada Turbin Terhadap Efisiensi Pembangkit Listrik Tenaga Mikrohidro (PLTMH)," Proton, vol. 5, no. 1, pp. 34-39, 2013.

[9] A. Zakaria, M. Welly, and M. Cambodia, "Model Stokastik Curah Hujan Harian dari Beberapa Stasiun Curah Hujan di Way Jepara," J. Rekayasa (Jurnal Tek. Sipil dan Perencanaan), vol. 19, no. 2, pp. 107-118, 2005.

\section{Biodata Penulis}

Dean Corio, menyelesaikan studi Strata 2 di Jurusan Teknik Elektro Universitas Andalas tahun 2014, pada tahun 2015 diterima sebagai dosen Teknik Elektro di Institut Teknologi Sumatera. 
Riset yang dikembangkan adalah renewable energy, smart home dan smart grids.

Kiki Kananda, Merupakan alumni Teknik Elektro Universitas Andalas Tahun 2013, sekarang merupkan dosen Teknik Elektro Institut Teknologi Sumatera. Riset yang dikembangknag adalah elektronika daya dan sistem pembangkitan.

Khansa Salsabila S, Merupakan mahsiwa Teknik Elektro Institut Teknologi Sumatera 